\title{
Profile of patients admitted in a pulmonology ward and developing Clostridium difficile enterocolitis
}

Ioana Cojocaru1', Livia Luculescu², Daniela Negoescu², Irina Strâmbu²,3,†

${ }^{1}$ 'Carol Davila' University of Medicine and Pharmacy, Bucharest, Romania

'Marius Nasta' Institute of Pneumophthysiology, Bucharest, Romania

${ }^{3}$ Department of Pulmonology, University of Medicine and Pharmacy, 'Carol Davila' Bucharest, Romania

Abstract

English:

Clostridium difficile is an anaerobic bacterium than can colonise the lower intestine and cause enterocolitis in susceptible patients. Clostridium difficile infection (CDI) is typically a nosocomial infection, favoured by treatment with antibiotics (especially with broad-spectrum drugs), proton pump inhibitors, but also comorbidities, old age and prolonged hospitalisation. Based on the observation that in the past years, the frequency of nosocomial CDI has increased in the Institute of Pulmonology, Bucharest, this retrospective observational study aimed to analyse the characteristics of admitted patients who develop CDI, in order to identify possible particular features and risk factors. Accordingly, medical files from 80 patients admitted from January 2015 to August 2017 were analysed for demographic data, respiratory diagnosis, comorbidities, blood tests, treatments prescribed, time of CDI onset, evolution and outcome. The number of patients studied was 29 in 2015, 16 in 2016 and 35 in 2017, with slight male predominance. Totally, 54 patients (67.5\%) had tuberculosis (pulmonary or pleural), 12 had lung cancer, five had respiratory infections, two had chronic obstructive pulmonary disease and seven had other diseases. All patients but nine were receiving antibiotics: tuberculosis drugs, cephalosporins, fluoroquinolones and beta-lactams. About half of the patients received proton pump inhibitors. Most patients had several comorbidities. Mean time since admittance to onset of diarrhoea was 20 days. CDI was treated with metronidazole or vancomycin. The evolution was favourable in $90 \%$ of patients, but eight patients (10\%) died.

This study highlights a high frequency of CDI in patients treated for tuberculosis. Due to insufficient data, no epidemiological consideration could be made. Further studies are needed to assess the relationship among tuberculosis, tuberculosis treatment and CDI.

Keywords

Clostridium difficile infection $•$ antibiotics $•$ tuberculosis $•$ TB drugs

\section{Profilul pacienților internați într-un serviciu de pneumologie care dezvoltă enterocolită cu Clostridium difficile}

Rezumat
Romanian:
Clostridium difficile este o bacterie anaerobă ce poate coloniza colonul și genera o enterocolită la pacienții susceptibili. Infecția cu Clostridium difficile (ICD) este de regulă o infecție nosocomială, favorizată de tratamentul cu antibiotice (în special cu spectru larg), inhibitori de pompă de protoni, dar și de comorbidități, vârsta înaintată și spitalizarea prelungită. Pe baza observației că în ultimii ani frecvența ICD nosocomiale a crescut în Institutul de Pneumologie București, acest studiu retrospectiv observațional și-a propus să analizeze caracteristicile pacienților internați care au dezvoltat ICD, pentru a identifica posibile particularități și factori de risc.
Documentele medicale a 80 de pacienți internați din ianuarie 2015 până în august 2017 au fost studiate, extrăgându-se date demografice, diagnosticele respiratorii, comorbiditățile, analizele de sânge, tratamentele prescrise, momentul apariției ICD, evoluția și rezultatul.

'Corresponding author: Irina Strâmbu

E-mail: istrambu@yahoo.com

ว Open Access. (C 2019 Cojocaru et al., published by Sciendo

(c) Br-NC-ND This work is licensed under the Creative Commons Attribution-NonCommercial-NoDerivs 4.0 License. 
Numărul de pacienți studiați a fost 29 în 2015, 16 în 2016 și 35 în 2017, cu o ușoară predominanță masculină. Cincizecișipatru pacienț (67,5\%) aveau tuberculoză (pulmonară sau pleurală), 12 - cancer pulmonar, 5 - infectii respiratorii, 2 - BPOC, 7 - alte boli. Toți pacienții, cu excepția a nouă, au primit antibiotice: antituberculoase, cefalosporine, fluoroquinolone și beta-lactamine. Aproximativ jumătate din pacienți au primit inhibitori de pompa de protoni. Majoritatea pacienților aveau mai multe comorbidități. Timpul mediu de la internare până la debutul diareei a fost de 20 de zile. ICD a fost tratată cu metronidazole sau vancomicină. Evoluția a fost favorabilă la $90 \%$ din pacienți, dar 8 pacienți (10\%) au decedat.

Acest studiu atrage atenția asupra frecvenței ridicate a ICD la pacienții tratați pentru tuberculoză. Datorită datelor insuficiente, nu s-au putut face considerații epidemiologice. Sunt necesare studii viitoare pentru a evalua relația dintre tuberculoză, tratamentul antituberculos și ICD.

Cuvinte-cheie

infecție cu Clostridium difficile • antibiotice • tuberculoză • medicamente antituberculoase

\section{Introduction}

Clostridium difficile (C. diff) is an anaerobic bacterium that can cause symptoms ranging from simple diarrhoea to life-threatening conditions of the colon. Enterocolitis caused by $C$. diff commonly occurs in adults admitted in hospitals or long-term care facilities, typically after antibiotic treatment. The past decades have witnessed an increase in the incidence of enterocolitis caused by $C$. diff infection (CDI), sometimes in individuals not previously considered at risk for this nosocomial disease (young persons, with no antibiotic or health facility exposure).

The incidence is about 15 cases in 1,000 patients admitted in hospital and about 20 cases in 100,000 inhabitants (1). CDI can be very severe and even deadly. Mortality directly related to the infection was considered to be $5 \%$, while mortality of any cause in patients with ECD can go up to $15 \%-20 \%$ (1). Based on the clinical observation that in the past years, CDI, which was very rare a decade ago, is indicated increasingly often in patients admitted for respiratory diseases in a tertiary pulmonology hospital, this research aimed to go deeper into the observation of the characteristics of patients who develop this nosocomial infection.

\section{Aims of the study}

The study aimed to analyse the characteristics of patients admitted for respiratory diseases who develop $C$. diff enterocolitis, to identify the respiratory diseases most likely to be associated with ECD and to identify the risk factors for this nosocomial infection.

\section{Materials and methods}

This is a retrospective observational descriptive study. The medical documents of patients admitted to 'Marius Nasta' Institute of Pneumophthysiology for various respiratory conditions between January 2015 and August 2017 and who developed an enterocolitis with $C$. diff were analysed. Enterocolitis with $C$. diff was defined as diarrhoea (emission of at least three loose stools per day, accompanied or not by abdominal pain and flatulence) with positive Clostridium test in stool. The stool of patients with diarrhoea was tested for $C$. diff toxins $A$ and $B$ and glutamate dehydrogenase (GDH) antigen, using a mini-VIDAS system. Information recorded from the patients' files were demographic data (gender, age and domicile), individual data (weight, as well as laboratory tests - erythrocyte sedimentation rate [ESR], white blood cell [WBC] count, haemoglobin and associated diseases), data regarding the respiratory disease (diagnosis and treatment), data about CDI (duration from admittance to onset of diarrhoea, as well as treatment), evolution and outcome.

The diagnosis of the respiratory disease was based on medical history, symptoms and specific investigations. The respiratory diseases were grouped into six categories:

1. Pulmonary tuberculosis (TB)

2. Tuberculous pleurisy

3. Lung cancer

4. Respiratory infection (including pneumonia, lung abscess and others)

5. Chronic obstructive pulmonary disease (COPD)

6. Others, including pulmonary embolism, bronchiectasis, trauma and interstitial lung diseases.

Data collected were included and processed in Excel 2010. Data from 100 patients were collected, but finally, data for only 80 patients were analysed, due to lack of complete information for the other patients.

\section{Results}

Information regarding 80 patients admitted between January 2015 and August 2017 for respiratory conditions and who developed CDI was analysed. 
Table 1. Respiratory diseases for which the patients were admitted

\begin{tabular}{|c|c|c|c|c|c|c|c|c|}
\hline \multirow{3}{*}{$\begin{array}{c}\text { Respiratory diagnosis } \\
\text { Pulmonary TB }\end{array}$} & \multicolumn{8}{|c|}{ Number of cases (\%) } \\
\hline & \multicolumn{2}{|c|}{2015} & \multicolumn{2}{|c|}{2016} & \multicolumn{2}{|c|}{2017} & \multicolumn{2}{|c|}{ Total } \\
\hline & 14 & $48.27 \%$ & 11 & $68.75 \%$ & 21 & $60 \%$ & 46 & $57.5 \%$ \\
\hline TB pleurisy & 4 & $13.79 \%$ & 0 & 0 & 4 & $11.42 \%$ & 8 & $10 \%$ \\
\hline TB total & 18 & $62.06 \%$ & 11 & $68.75 \%$ & 25 & $71.42 \%$ & 54 & $67.5 \%$ \\
\hline Lung cancer & 4 & $13.79 \%$ & 3 & $18.75 \%$ & 5 & $14.28 \%$ & 12 & $15 \%$ \\
\hline Infection & 1 & $3.44 \%$ & 1 & $6.25 \%$ & 3 & $8.57 \%$ & 5 & $6.25 \%$ \\
\hline COPD & 0 & 0 & 1 & $6.25 \%$ & 1 & $2.85 \%$ & 2 & $2.5 \%$ \\
\hline Other & 6 & $20.68 \%$ & 0 & 0 & 1 & $2.85 \%$ & 7 & $8.75 \%$ \\
\hline Total & 29 & & 16 & & 35 & & 80 & \\
\hline
\end{tabular}

Notes: TB = tuberculosis; COPD = chronic obstructive pulmonary disease.

The patients included 37 women and 43 men, with a mean age of 55 years (between 19 years and 82 years). Most patients were aged $50-59$ years (16 patients) and $70-79$ years (16 patients).

Forty-seven patients (59\%) had urban domicile, and 32 were living in rural areas.

The respiratory diseases for which the patients were admitted in the 3 years analysed are shown in Table 1, depicted in the six diagnostic groups.

The mean duration since the admittance in hospital to the onset of diarrhoea was 20 days, with a minimum of 1 day and a maximum of 122 days. In nine patients, this information was not available in the medical documents.

The treatment before the onset of diarrhoea in 54 (67.5\%) patients was an antituberculous regimen (isoniazid, rifampicin, pyrazinamide and ethambutol); other antibiotics used were cephalosporin (16 patients - 20\%), levofloxacin (eight patients - 10\%), ciprofloxacin (five patients - 6.25\%), and amoxicillin-clavulanate (seven patients $-8.75 \%$ ). Nine patients $(11.25 \%$ ) did not receive any antibiotic for the respiratory disease before the onset of diarrhoea.

Thirty-one patients $(38.75 \%)$ were administered a protein pump inhibitor (PPI) (omeprazole) and 14 patients (17.5\%) received an $\mathrm{H} 2$ receptor blocker (ranitidine).

In 15 patients $(18.75 \%)$, a systemic corticosteroid was associated (intravenous hydrocortisone or oral methylprednisolone).

Blood tests performed on the admitted patients were the usual laboratory tests (haemoglobin, WBC count, ESR, liver enzymes, creatinine and blood urea nitrogen). The mean value of ESR was $53 \mathrm{~mm} / \mathrm{hour}$, with more than half of the patients having a value $>40 \mathrm{~mm} /$ hour. Haemoglobin value was found in the documents of 76 patients, with a mean value of $12 \mathrm{~g} / \mathrm{dL}(12.61 \mathrm{~g} / \mathrm{dL}$ for male patients and $11.48 \mathrm{~g} / \mathrm{dL}$ for female patients). Thirty-five patients (46\%) had haemoglobin values $<12 \mathrm{~g} / \mathrm{dL}$, with a minimum value of $8.2 \mathrm{~g} / \mathrm{dL}$.
WBC count could be found for 77 patients. There were four patients $(5.19 \%)$ with WBC count $<5,000$ cells $/ \mathrm{mm}^{2}$, 39 patients $(50.64 \%)$ with normal WBC count, and 34 patients $(44.15 \%)$ with elevated WBC $\left(>10,000 / \mathrm{mm}^{2}\right)$. Eleven patients had WBC count $>15,000 / \mathrm{mm}^{2}$, with one of the patients having WBC $>30,000 / \mathrm{mm}^{2}$.

Besides the respiratory disease for which they were admitted into hospital, 66 patients $(82.5 \%)$ also had various comorbidities:

- Heart disease: 21 patients

- Arterial hypertension: 19 patients

- Other respiratory disease (bronchitis, pulmonary embolism, emphysema, infarction): 14 patients

- Anaemia: 12 patients

- Liver disease (chronic hepatitis, liver cirrhosis, elevated liver enzymes): 12 patients

- Bronchiectasis: 11 patients

- Diabetes mellitus: 10 patients

- Neurologic diseases (epilepsy, Parkinson, paresis): 10 patients

- Obstructive lung diseases: 10 patients

- Cancer (other than lung cancer): nine patients

- Renal failure: eight patients

- Respiratory failure: four patients

- Cachexia: four patients

- Non-TB pleural effusion: four patients

- Gastrointestinal diseases: three patients

- Bone diseases: two patients

After the onset of diarrhoea and the proven presence of $C$. diff, all patients received treatment with metronidazole or vancomycin, according to the local guidelines.

The evolution of ECD was favourable in $90 \%$ of the patients and unfavourable in eight patients, who died (10\%). The mortality decreased constantly over the 3 years studied: in 2015, there were six deaths (20.68\%); in 2016, there was one death (6.25\%); and in 2017, one death was recorded (2.85\%) (Figure 1). 


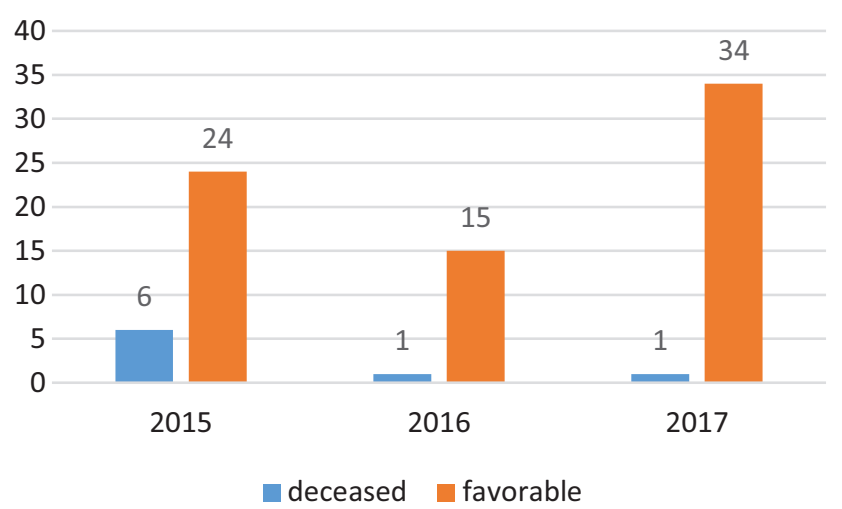

Figure 1. Outcome of $\mathrm{CDI}$ (number of cases) in the 3 years studied.

\section{Discussion}

The microbiome comprises the entire population of microorganisms present in a tissue or biofluid, and it includes bacteria, fungi, viruses and protozoa. Historically, over thousands of years, a reciprocally beneficial relationship has developed between the human host and its 'guests'. Microbes, which thrive on the human body, are involved in the normal functions of the host, such as metabolism, defence or reproduction (2). The composition of the microbiome differs from one healthy individual to another; however, there is a predominance of specific germs at particular anatomic sites, such as Streptococcus species dominating the oral flora. The gut microbiota is dominated by anaerobes, but in the caecum and lower intestine, aerobic bacteria are more frequent. Most bacteria belong to Bacteroides, Clostridium, Faecalibacterium, Eubacterium, Peptococcus, Peptostreptococcus and Bifidobacterium, but Escherichia and Lactobacillus species are also present (3).

C. diff is a Gram-positive anaerobic bacillus, existing in two forms: vegetative or sporulated. The Clostridium bacilli are large, in pairs or chains, displaying cilia. In the sporulated form, they survive in harsh environments and are resistant to usual sterilisation methods (high temperature, ultraviolet light, antibiotics and disinfectants). The spores may persist in the gut after eradication of the vegetative form, generating recurrences of the disease. The virulence of $C$. diff is determined by the toxins $A(T c d A)$ and $B(T c d B)$, which are among the most aggressive bacterial toxins known (4).

About $60 \%$ of healthy adults have detectable serum levels of antibodies (immunoglobulins $\lg A$ and $\lg G$ ) against $A$ and $B$ toxins (5). High levels of $\lg G$ against $T c d B$ are associated with a milder form of disease in patients with active infection (4). High levels of antibodies against TcdA are noted in healthy carriers, while low levels are associated with severe disease and recurrence of infection (4).
In susceptible individuals, $C$. diff colonises the colon and can cause enterocolitis by exotoxin production. The infection is transmitted orally by the spores, present in abundance in health care facilities and in lower amounts in food or the environment (1). So, both nosocomial and community modes of transmission are possible. Not all colonised individuals develop symptoms. In children, for instance, colonisation is very frequent, but symptoms rarely appear, possibly due to the reduced number of toxin receptors in their colon (1).

Anyway, the past 2 decades have witnessed the emergence of a hypervirulent strain of $C$. diff, ribotype 027 , producing much higher levels of toxins A and B (6). In Europe, the frequency of CDI increased consistently in Romania also, where a higher percentage of ribotype 027 (about $70 \%$ ) is encountered (7).

The major risk factor for the occurrence of the disease is the antibiotic treatment, which destroys the normal gut microbiota. The colon is the preferred site of CDI due to the anaerobic medium and the absence of competing normal flora (4). Other risk factors are old age, cancer chemotherapy and severe comorbidities (1). The PPIs increase the risk for CDI up to $65 \%(8,9)$, as well as increasing the risk for the recurrence of infection. By decreasing the gastric acidity, PPIs facilitate the oral access of bacteria in the intestine. PPIs also reduce the presence of Bifidobacterium spp., with many of these species having a role in the prevention of CDI (10).

The clinical expression of the CDI is determined by the virulence of the bacteria and the host's immune response. The diarrhoea in CDI is mediated by A and B toxins, which cause necrosis of the colonic epithelial cells, loss of functional intestinal barrier and neutrophilic colitis (1).

The symptoms consist of mild-to-moderate diarrhoea, which is not bloody, usually associated with abdominal cramps, anorexia and malaise. Patients can also have fever, dehydration and abdominal tenderness, but some patients can develop toxic megacolon (11). A CDI should be suspected if the patient had antibiotic treatment in the past 3 months, has been recently hospitalised, or if diarrhoea occurs $\geq 48$ hours after a hospitalisation (12).

Typically, the CDI is diagnosed by enzymatic immune testing for toxins in the faeces or by genetic DNA testing that identifies bacterial genes responsible for toxin coding in the loose stool (1). Cultivation of the bacteria is rarely used in clinical practice, as it needs anaerobic culture media.

Treatment is based on metronidazole or vancomycin, in monotherapy, with equivalent effects. For the relapses, vancomycin is recommended, with a prolonged duration of treatment (13). Over time, C. diff develops some resistance to these classic drugs.

It has been suggested that other antibiotics, such as rifampicin, rifaximine, linezolid or beta-lactams, also could be efficient in the treatment of $\operatorname{ECD}(14,15)$. 
In severe recurrent infections, the use of other therapeutic means is discussed: bacteriotherapy by means of faecal transplantation, bowel irrigation or surgery.

It has been repeatedly demonstrated that CDI is associated with antibiotic treatments, which affect the gut microbiota and make way for the development of $C$. diff. Any antibiotic treatment can induce gut microbiota imbalance, but a higher risk is associated with long-term use of broad-spectrum antibiotics. The strongest association has been shown for clindamycin, followed by cephalosporins, monobactams, carbapenems, fluoroquinolones, penicillins, macrolides and trimethoprim/sulphonamides. Tetracycline is not associated with the risk of CDI $(16,17)$.

The association between TB treatment and CDI has been less studied, until recently. An outbreak of CDI in patients admitted with TB in Poland identified a hypervirulent ribotype 046 strain of $C$. diff, resistant to moxifloxacin, rifampicin, erythromycin and clindamycin (18).

Another study showed an incidence of 2.83 cases of CDI in 1,000 patients with TB and a mortality of $1.9 \%$ (19).

It seems that the antibiotics commonly used for the treatment of TB (isoniazid, rifampicin, ethambutol and pyrazinamide-HRZE) can induce changes in the microbiota composition. Among these drugs, only rifampicin is a broad-spectrum bactericidal antibiotic, the others having a narrow spectrum directed against mycobacteria. HRZE treatment induces a 10-fold reduction in Blautia, a >200-fold reduction in Lactobacillus and Coprococcus as well as a 675-fold decrease in Ruminococcus compared to the group of patients treated for latent TB infection (20).

The long duration of TB treatment induces long-standing disruption in the gut microbiota, persisting long after the stopping of TB treatment. It was shown in South African cohorts that $C$. diff strains involved in CDI in patients treated for TB have high levels of resistance to rifampicin and fluoroquinolones (including moxifloxacin), a feature of the $C$. diff populations circulating among TB patients $(21,22)$.

In our study, we noticed a predominance of old age, a slight predominance of male subjects and urban domicile in patients with CDI. Most patients had several associated comorbidities, some severe, reducing the host defences against infection. It is interesting that a high proportion of patients had anaemia, which may be a consequence of the multiple comorbidities and which may play a role as a separate risk factor for CDI. Only half of the patients were receiving PPIs, yet the indication for such treatment is questionable, as only very few patients had gastrointestinal comorbidities. There is a clinical habit of 'protecting' the stomach against the possible digestive intolerance of TB drugs and prescribing PPIs even in the absence of digestive symptoms. This habit should be discouraged.

The main finding of our study is the high proportion of patients receiving TB treatment in comparison with patients with other respiratory diseases and other antibiotic treatments. It should be mentioned that our institution is dedicated to all respiratory diseases, and less than one third of patients are admitted for TB. The figure of $67.5 \%$ of patients with TB in our group suggests that patients with TB are at a higher risk of developing CDI than are other patients. TB patients are typically admitted after diagnosis for the initial phase of treatment (HRZE daily) and remain in hospital for a mean duration of 30 days. The mean duration of hospitalisation for other diagnoses is 9 days. The longer duration of hospitalisation for TB patients may be a supplemental risk factor for the occurrence of CDI.

Another fact that can be noticed is the shift of proportion of patients with TB and other diagnoses in the 3 years studied, with a decrease of $\mathrm{CDI}$ in various respiratory patients and an increase in the proportion of TB patients. In parallel, there is a decrease of mortality in the 3 years, suggesting milder forms of CDI in TB patients. This could be explained by the enforcement of the prophylactic measures taken in the hospital after the initial occurrence of severe and lethal CDI cases in 2015 (disinfection, rapid diagnosis of CDI after initial suspicion and isolation). These measures diminished the occurrence and severity of CDI in patients with various respiratory diseases but failed to influence the occurrence of CDI in TB patients. The longer hospitalisation, as well as the persistence of possible sources of infection in the TB departments (geographically separated from the other wards), could explain the maintenance of CDI in these patients.

A recent study demonstrated that the incidence of CDI in hospitalised patients is related to the presence of CDI inpatients previously hospitalised in the same beds, suggesting the persistence of spores in the environment (23). A predisposition of TB patients to CDI of other types could also be detected (such as genetic susceptibility to mycobacteria and CDI, or a pathogenic role of mycobacteria in the host's immune defence against $C$. diff).

There are several limitations of our study. The most important was the inability to recover all the patient files for the patients notified with CDI in the period analysed. Moreover, many of the patient files had missing information. These problems prevented us from making epidemiological generalisations. Furthermore, the study was performed on a limited number of patients.

\section{Conclusions}

CDI is an increasing health care problem for hospitalised patients, due to the high incidence of hypervirulent strains of $C$. diff identified in recent years and the resistance of the sporulated form to disinfection measures. Even if, traditionally, treatments with broad-spectrum antibiotics were considered to be the main risk factor for development of CDI, in high-TB-prevalence countries, such as Romania, $\mathrm{CDI}$ is a higher problem among TB patients, which is 
associated with long hospitalisations, long-term antibiotic treatment and infection with strains resistant to rifampicin and fluoroquinolones.

Studies on higher number of patients are needed, for epidemiological comparisons and assessment of risk factors.

\section{Ethics approval and consent to participate}

Not applicable (retrospective study).

\section{Competing interests}

The authors declare that they have no competing interests.

\section{References}

1. Leffler DA, Lamont JT. Clostridium difficile infection. The New England Journal of Medicine. 2015;372:1539-1548.

2. Jandhyala SM, Talukdar R, Subramanyam C, Vuyyuru H, Sasikala M, Reddy N. Role of the normal gut microbiota. World Journal of Gastroenterology. 2015, 8787-8803.

3. Guarner F, Malagelada J. Gut flora in health and disease. The Lancet. 2003. 361(9356): 512-519.

4. Heinlen L, Ballard JD. Clostridium difficile infection. The American Journal of the Medical Sciences. 2010;340(3): 247-252.

5. Leffler DA, Lamont JT. Treatment of Clostridium difficile-associated disease. Gastroenterology. 2009; 136(6):1899-1912.

6. Pepin J, Valiquette L, Alary ME, et al. Clostridium difficileassociated diarrhea in a region of Québec from 1991 to 2003: a changing pattern of disease severity. CMAJ. 2004;171:466-472.

7. Benea S, Popescu GA, Badicut I, Florea D, Petrache D, Gavriliu $\mathrm{L}$, et al. Clostridium difficile infections hospitalized in Romanian Institute of Infectious Diseases during the first three months of 2012. Poster Presentation, 4th International C. difficile Symposium, September 20-22, Bled, Slovenia.

8. Janarthanan S, Ditah I, Adler DG, et al. Clostridium difficileassociated diarrhea and proton pump inhibitor therapy: a meta-analysis. The American Journal of Gastroenterology. 2012;107:1001-1110.

9. Leonard J, Marshall JK, Moayyedi P. Systematic review of the risk of enteric infection in patients taking acid suppression. The American Journal of Gastroenterology. 2007;102:2047-2056.

10. Imhann F, Bonder MJ, Vich Vila A, Fu J, Mujagic Z, Vork L, et al. Proton pump inhibitors affect the gut microbiome. Gut. 2016;65(5):740-748. doi: 10.1136/gutjnl-2015-310376. Epub https://emedicine.medscape.com/article/186458-overview [Accessed 2nd March, 2019].

11. McDonald LC, Coignard B, Dubberke E, Song X, Horan T, Kutty PK. Recommendations for surveillance of Clostridium difficile-associated disease. Infection Control \& Hospital Epidemiology. 2007; 28(2):140-145 (ISSN: 0899-823X).

12. Popescu GA, Szekely E, Codita I, Talapan D, Serban R, Ruja G. Ghid de diagnostic, tratament si prevenire a infectiilor determinate de Clostridium difficile. Bucharest 2016. Available from: http://mainicurateinspitale.ro/wp-content/uploads/2016/08/ Ghid-diagnostic-tratament-si-prevenire-Clostridium-difficile.pdf. [Accessed 2nd March, 2019].

13. Pepin J. Improving the treatment of Clostridium difficile-associated disease: where should we start? Clinical Infectious Diseases. 2006, 43(5):553-555.

14. Musgrave CR, Bookstaver PB, Sutton SS, Miller AD. Use of alternative or adjuvant pharmacologic treatment strategies in the prevention and treatment of Clostridium difficile infection. The International Journal of Infectious Diseases. 2011;15:e438-e448.

15. Brown KA et al. Meta-analysis of antibiotics and the risk of community-associated Clostridium difficile infection. Antimicrobial Agents and Chemotherapy. 2013; 57:2326. Available from: http://dx.doi.org/10.1128/AAC.02176-12.

16. Deshpande A et al. Community-associated Clostridium difficile infection and antibiotics: a meta-analysis. Journal of Antimicrobial Chemotherapy. 2013 Apr 25; [e-pub ahead of print]. Available from: http://dx.doi.org/10.1093/jac/dkt129.

17. Obuch-Woszczatyński P, Dubiel G, Harmanus C, Kuijper E, Duda U, Wultańska D, van Belkum A, Pituch H. Emergence of Clostridium difficile infection in tuberculosis patients due to a highly rifampicinresistant PCR ribotype 046 clone in Poland. European Journal of Clinical Microbiology \& Infectious Diseases. 2013; 32:1027-1030. Available from: doi: 10.1007/s10096-013-1845-5.

18. Lee YM, Huh KC, Yoon SM, Jang BI, Shin JE, Koo HS, et al. Incidence and clinical outcomes of Clostridium difficile infection after treatment with tuberculosis medication. Gut and Liver. 2016; 10(2): 250-254.

19. Wipperman MF, Fitzgerald DW, Juste MAJ, Taur Y, Namasivayam S, Sher A, et al. Antibiotic treatment for tuberculosis induces a profound dysbiosis of the microbiome that persists long after therapy is completed. Scientific Reports. 2017;7:10767. Published online 2017 Sep 7. doi: 10.1038/s41598-017-10346-6.

20. Kullin BR, Reid S, Abratt V. Clostridium difficile in patients attending tuberculosis hospitals in Cape Town, South Africa, 2014-2015. African Journal of Laboratory Medicine. 2018;7(2): a846. Available from: https://doi. org/10.4102/ajlm.v7i2.846.

21. Legenza L, Barnett S, Rose W, Bianchini M, Safdar N, Coetzee R. Epidemiology and outcomes of Clostridium difficile infection among hospitalised patients: results of a multicentre retrospective study in South Africa. BMJ Global Health. 2018;3:e000889. doi:10.1136/bmjgh-2018-000889.

22. Freedberg DE, Salmasian H, Cohen B, Abrams JA, Larson EL. Receipt of antibiotics in hospitalized patients and risk for Clostridium difficile infection in subsequent patients who occupy the same bed. JAMA Internal Medicine. 2016, 176(12): 1801-1808. doi:10.1001/jamainternmed.2016.6193. 